\title{
MODELLING DOMINANT LANGUAGE PEDAGOGICAL PRACTICES TO IMMERSE ARABIC LEARNERS
}

\author{
Saheed Ahmad Rufai \\ Sokoto State University, Nigeria \\ P.M.B. 2134, Birnin Kebbi Road, Sokoto State, Nigeria \\ E-mail: abmadrufaisabeednen@yahoo.com
}

\begin{abstract}
The achievements of language pedagogical models have been studied through the use of input-output models. While teaching and learning programmes are the input, learners' achievements are the output. However, some specific models have been found to be more effective and evaluated more than others. It is noted that of all the components of language pedagogical models, the specific language learning strategies employed have received less attention. This study evaluates four dominant language pedagogical models namely the Alliance Francaise Model (for French), the Goethe Institut Model (for German), Instituto Cervantes Model (for Spanish), and the model the European-funded Pan-European Task-based Activities in Language Learning (PETALL) project which is co-funded by the Lifelong Learning Programme of the European Union. Consequently, the strengths identified are reformulated as principles guiding best language pedagogical practices and translated into curriculum conceptual and design framework for a proposed and tentatively tagged, "The Arabic World". The ultimate purpose wass to replicate some of such successful outcome-based dominant language pedagogical practices in the context of Modern Standard Arabic.
\end{abstract}

Keywords: $\quad$ Arabic learners, pedagogical model, learning strategies

\section{Introduction}

The centrality of the role of language in social change and development has received its deserved attention in the literature for more than a century. ${ }^{1}$ 'Language

${ }^{1}$ Cummins James, ed. "Bilingual and Immersion Programs", in The Handbook of Language and Teaching, ed. Moore. Long \& Cane Doughty. (Malden: Wiley Blackwell, 2010), 161-181. 


\section{Arabiyât Jurnal Pendidikan Bahasa Arab dan Kebahasaaraban, 8 (1), 2021}

skills are a crucial prerequisite for communication across country borders ${ }^{2}$ and for the international mobility of people and goods. ${ }^{3}$ In making international migration decisions common languages, linguistic distance, language education are prominent among the factors that normally affect choices. ${ }^{4}$ The effect of language skills on wages is largely positive and its influence on employment probabilities is far-reaching. ${ }^{5}$ In the area of international trade or broad economic fronts, language skills have significantly fulfilled the role of a booster and an attraction. ${ }^{6}$ Yet, attention to language pedagogy in sophisticated scholarship is barely half-a-decade old, having been recorded only in the 1970 s. $^{7}$ It is equally noteworthy that notwithstanding the importance of language skills and despite the correlations between the use of appropriate language learning strategies and successful language learning, 8 only very few works have traced the history and development of language learning strategies research through engagement with diverse dimensions of language learning. ${ }^{9}$

It is almost a consensus among language pedagogies that teaching approaches, methods and procedures are always being reassessed in the light of new ideas that keep emerging. ${ }^{10}$ Such experience is regarded as a product of the growing complexity of the means of communication and the opportunities created by technology that put language skills in new uses. In a similar token are such considerations as "the political, social and economic impact of globalization, the new demands of the labour market that result from it, the pursuit of competitiveness, the challenges of intercultural communication and the diversification of culture" all of which are considered as "phenomena that have opened new perspectives on the central role that foreign languages have come to play in the development of contemporary societies"11. There is no gainsaying that such an atmosphere has a great potential to alter the landscape of

2 Catherine Monnier, Julie Booiche, Pauline Armandon, Sophie Baodoin, and Stephanie Bellocchi, "Is bilingualism associated with better working memory capacity: A meta analysis", International Journal of Bilingual Education and Bilingualism, Vol. 5, No. 4, 2021, 172-187.

3 Cummins James, Language, Power and Pedagogy: Bilingual Children in Crossfire, (Clevedon: Multilingual Matters, 2000), 17.

${ }^{4}$ Baker Collins, Foundation of Bilingual Education and Bilingualism, (Clevedon: Multilingual Matters, 2007), 97.

${ }^{5}$ Freeman Roy, Bilingual Education and Social Change, (Clevedon: Multilingual Matters, 1998), 26.

${ }^{6}$ Melissa Navarro Martell, "Ciencias bilingues: how dual language teachers cultivate equity in dual language classrooms", International Journal of Bilingual Education and Bilingualism, Vol. 5, No. 4, 2021, 199-211.

${ }^{7}$ Cummins James, ed. "Bilingual and Immersion Programs", 51.

${ }^{8}$ Redab Al-janaideh, Kathleen Hipfner, Boucher, Patricia Cleave, Xi Chen, "Contributions of code-based and oral language skills to Arabic and English reading comprehension in Arabic-English bilinguals in the elementary school years", International Journal of Bilingual Education and Bilingualism, Vol. 5, No. 4, 2021, 212--223.

${ }^{9}$ Cummins James, ed. "Bilingual and Immersion Programs", 172.

${ }^{10}$ Georgios and Charalambos Themistocleaous, "Vowel learning in diglossic settings: Evidence from Arabic-Greek learners", International Journal of Bilingualism, July 2020, 135-150.

${ }^{11}$ Freeman Roy, Bilingual Education and Social Change, 34-36. 


\section{Arabiyât Jurnal Pendidikan Bahasa Arab dan Kebahasaaraban, 8 (1), 2021}

foreign language learning ${ }^{12}$ especially in because the learners' possible clamour for efficacious evidence-based language teaching models.

The emerging concern over these considerations have stimulated the curiosity of language pedagogues and researchers, especially concerning methods and strategies with the potential to enhance the quality of achievement in language teaching and learning $^{13}$ according to such a concern, James ${ }^{14}$ opines that the field of second language teaching is now replete with studies on language learning strategies for specific contexts. According to him, such strategies can be unobservable mental operations such as selective attention or observable behaviours such as seeking out a conversation partner or both. In addition to that is the need for the involvement of "some degree of consciousness or awareness on the part of the learner because the element of choice is what gives a strategy its special character". ${ }^{15}$

It is easily derivable from the foregoing that the field of language teaching or language education is ever-changing and its challenges, ever-increasing. For instance, Roy identifies as challenges of language teaching and learning the assumption that language learning is easy, language teacher's attitude and belief, lack of precision in selecting instructional strategies and materials as well as the language combination which may rightly be characterized as the challenge of bilingual education. ${ }^{16}$ This marks the meeting point between the scholarship of language pedagogy and bilingual education. It is therefore not out of place to subject this to a search-light, in what follows, because of its significance to the subject of this project.

Bilingual education is a subject with a great potential to generate continued public and policy debates. ${ }^{17}$ The factors propelling such debates may be traceable to the divergent nature of understandings among contributors, concerning the concept of bilingual education and the nature of such an education. ${ }^{18}$ May identifies a group of commentators as classifying as bilingual 'any educational approach adopted for, or directed at, bilingual students, irrespective of their educational aims (fostering bilingualism or monolingualism) or the role, (if any) of first language (L1) and second language (L2) as languages of instruction"19. According to May, what makes a system bilingual in the estimation of this category of commentators is the presence of bilingual students in the classroom. He also identifies another category of

\footnotetext{
12 Sonia Wilson, "To mix or not to mix: Parental attitudes towards translanguaging and language management choices", International Journal of Bilingualism, March 4, 2020, 58-76.

${ }^{13}$ Cummins James, Language, Power and Pedagogy: Bilingual Children in Crossfire, 86; Cummins James, ed. "Bilingual and Immersion Programs", 170; Freeman Roy, Bilingual Education and Social Change, 7.

${ }^{14}$ Cummins James, ed. "Bilingual and Immersion Programs", 53.

${ }^{15}$ Cummins James, ed. "Bilingual and Immersion Programs", 55.

${ }^{16}$ Freeman Roy, Bilingual Education and Social Change, 34-36.

17 Sawyer May, "Bilingual Education: What the Research Tells Us", in Bilingual and Multilingual Education, eds. Garcia et al, Switzerland: Springer International Publishing, 2017, 122-131.

18 Brochin, Car, "Queering bilingual teaching in elementary schools and in bilingual teacher education" Theory into Practice, 2019, 80-88.

19 Sawyer May, "Bilingual Education: What the Research Tells Us”, 125.
} 


\section{Arabiyât Jurnal Pendidikan Bahasa Arab dan Kebahasaaraban, 8 (1), 2021}

commentators as those who "distinguish clearly between non-bilingual, weak, and strong bilingual programs" 20 Yet other see bilingual education as being no more than a system of education targeted at instilling in the students' ability to use two languages naturally. ${ }^{21}$

It is suggested that a bilingual education is that which makes a person speak or use two languages correctly. It has been further argued that 'it is impossible to find one definition that can satisfy all the various combinations of languages, nationalities, grammar rules, political and cultural environment, and all other variables that make bilingualism such a complex and delicate field". ${ }^{22}$ Accordingly, a bilingual person as the one who speaks equally two languages, who also acts appropriately in a sociocultural way in both languages and bilingual education is what brings about the ability to speak a second language using structures and concepts distinctive to the language, "instead of paraphrasing from the native language". ${ }^{23}$ The literature has captured some attempt at addressing this pedagogical dimension of bilingual education ${ }^{24}$ which is characterized as "instruction in two languages and the use of those two languages as mediums of instruction for any part or all, of the school curriculum" 25 may seems to have graphically captured the essence of bilingual education as articulated in the foregoing. ${ }^{26}$

May further rationalizes that it is required to have both languages involved, used as media of instruction for curriculum content delivery. "If there is a useful demarcation, then bilingual education may be said to start when more than one language is used to teach content (e.g. Science, Mathematics, Social Sciences, or Humanities) rather than just being taught as a subject by itself'. ${ }^{27}$ According to May, the teaching of majority students through a minority language as is the case in Frenchimmersion programs in Canada, and other examples of similar nature belong to the category of bilingual programs, owing to certain curricular and pedagogical implications. It is derivable from May's argument that the majority/minority question cannot be totally divorced from the scholarship of bilingual education. Yet it is May (2017) who graphically captures the essence of bilingual education where drawing extensively on existing literature, he argues that:

...bilingual education involves instruction in two languages... This immediately excludes programs that include bilingual students but which do not involve bilingual instruction, most notably submersion majority language programs, where students are taught only in the majority language,

${ }^{20}$ Sawyer May, "Bilingual Education: What the Research Tells Us", 122.

${ }^{21}$ Baker Mocinic, "Bilingual Education”, Professional Articles, Vol. 13, No. 6, 2011, 175-182.

${ }^{22}$ Baker Mocinic, "Bilingual Education", 180.

${ }^{23}$ Baker Mocinic, "Bilingual Education", 175.

${ }^{24}$ Agnieszka, Stepkowska, "Language experience of immigrant women in bilingual couples with Poles", International Journal of Bilingualism, July 23, 2020, 120-134.

25 Bialystok Earnest, "Bilingualism in Development: Language", Literacy and Cognition, (Cambridge: University Press, 2006), 34.

${ }^{26}$ Sawyer May, "Bilingual Education: What the Research Tells Us", 127.

${ }^{27}$ Sawyer May, "Bilingual Education: What the Research Tells Us", 129. 


\section{Arabiyât Jurnal Pendidikan Bahasa Arab dan Kebahasaaraban, 8 (1), 2021}

irrespective of their language background. It also excludes programs where an L2 is tanght as a subject only. English as a second language (ESL) classes, which include the sheltered instruction approach increasingly popular in the USA, are examples of this, as are foreign language classes. Along with submersion programs, they can also clearly be described as nonbilingual programs. ${ }^{28}$

It is unmistakable from the foregoing that language skills are of paramount importance to social change and development. ${ }^{29}$ This, as noted earlier, has been well documented in the literature. For communication across country borders and for the international mobility of people and goods, as well as international migration decisions, common languages, linguistic distance, language education have been identified as major determinants. ${ }^{30}$ The positive effect of such skills on wages, employment probabilities, economic opportunities at individual, national and international level cannot be overemphasized. That explains why developed countries are taking the lead globally in promoting their respective languages through the instrumentality of political and diplomatic machineries. ${ }^{31}$ Common knowledge are the place and status of such languages as German, Portuguese, and French at the international arena through attraction of foreign investment and rewarding economic exchanges to their national, regional or cross-national domains.

The perceived success of the various pedagogical practices involved in those languages has received scholarly attention from researchers at various levels. Consequently, the continuous research into them has contributed significantly to the enhancement of the quality of their pedagogical practices which has invariably translated into social, political and economic progress in the domains of such languages and beyond. There is a long-felt need to replicate such a successful experience in the context of Modern Standard Arabic (MSA) by modelling best pedagogical practices of dominant language teaching models alongside best practices in the dominant Arabic teaching models. The present study is therefore an undertaking of such a task to construct a curriculum framework for the proposed 'The Arabic World'.

The ultimate purpose of this project is to formulate curriculum conceptual and design principles for translation into a curriculum framework for The Arabic World. The attainment of this research task is targeted through the following specific objectives of the project:

1. To investigate the political, economic and cultural underpinnings of the dominant international language teaching models;

2. To examine the institutional nature of the dominant international language teaching models;

${ }^{28}$ Sawyer May, "Bilingual Education: What the Research Tells Us", 131

${ }^{29}$ Nina, Dobrushina, and Olga Kultepina, "The rise of lingua franca: The case of Russian in Dagestan”, International Journal of Bilingualism, October, 2020, 338-358.

30 Catherine Amanti, "The (invisible) work of dual language bilingual education teachers", Bilingual Research Journal, 2019, 455-470.

${ }^{31}$ Gloria Guzman and Cham Johannessen, eds., Bilingual Education: Politics, Policies and Practices in a Globalized Society, Springer, 2019. 


\section{Arabiyât Jurnal Pendidikan Bahasa Arab dan Kebahasaaraban, 8 (1), 2021}

3. To evaluate the program design model of each of the dominant international language teaching programs (with a focus on the interplay of the L1 and the L2 (this shall also involve a sociolinguistic survey);

4. To assess the levels of implementation of each of the dominant language teaching models within and outside its geographical coverage;

5. To evaluate the performance of the products of each of the language teaching models with a view to exposing the strengths and weaknesses of the programs;

6. To make recommendations for short-term pedagogical interventions and longterm curriculum measures which shall comprise,

i. Formulation of conceptual and design principles for the production of curriculum and materials for the teaching of Arabic as L2, in a maintenance and enrichment based model;

ii. Translation of such conceptual and design principles into peculiaritiesbased curricula for various settings;

iii. Production of curricula, methods, and materials for the teaching of Arabic for specific purposes;

iv. Systematic capacity building on Arabic language pedagogy, for teachers at various levels;

v. Experimentation on programme implementation at instructional level;

vi. Reproduction of revised and standardized Arabic education materials to learners; and

vii. Formulation of post-experimental principles and recommendations concerning measures to be taken to ensure credible outcomes of teaching Arabic as a foreign language.

Pursuant to such objectives as identified above, this project-focused research is guided by the following questions:

1. What are the political, economic and cultural underpinnings of the dominant international language teaching models?

2. What is the institutional nature of the dominant international language teaching models?

3. What is the nature of the design models of the dominant language teaching models?

4. To what extent have the various international language teaching models been implemented at national, regional and international levels?

5. What are the levels of achievement and performance of the products of each of the international language teaching models (with a focus on the strengths and weaknesses of the programmes that produce them)?; and

6. What are the short-term pedagogical interventions and long-term curriculum measures with potential to aid the realization of a credible Arabic language 


\section{Arabiyât Jurnal Pendidikan Bahasa Arab dan Kebahasaaraban, 8 (1), 2021}

education system, through the instrumentality of systematic answers to the following questions,

i. What are the conceptual and design principles for curriculum and materials development for teaching Arabic, in a maintenance and enrichment based model?

ii. How can such conceptual and design principles be translated into curriculum framework?

iii. How can innovative educational blueprints, methods, and materials appropriate for the teaching of Arabic language, be produced?

iv. What is the nature of the required capacity building for Arabic language teaching, for teachers?

v. How should revised and standardized Arabic education materials be reproduced? and

vi. What are the post-experimental principles and recommendations appropriate for measures to be taken in ensuring evidence-based outcomes of teaching Arabic?

Sequel to in the earlier enumeration of the political, economic, social, diplomatic, educational and cultural benefits of language skills it is pertinent to state that this study has the potential to aid the realization of such benefits, though the present paper restricts itself to only the first three objectives, leaving the other three as a subject of another paper. More importantly, the study has the potential to positively alter the landscape of the use of Arabic whose importance transcends cultural and religious boundaries. Given the fact that language builds bridges and eliminates barriers, the study has much to offer in benefits. Furthermore, policy makers across the globe may ultimately have to factor Arabic language consideration into their scheme of operations not only at international level but also in their domestic or national affairs.

\section{Method}

This study which is essentially of qualitative orientation, employed a combination of sociolinguistic survey method, historical method, curriculum criticism, analytical philosophy and creative synthesis. It was however intended to later incorporate some quantitative dimensions to measure learners' achievements in Arabic language at the experimental stage. In specific terms, sociolinguistic survey was conducted to examine the interplay of the L1 and the L2 in the context of Arabic language learning ${ }^{32}$ while the historical method facilitates the investigation of the historical backgrounds, political, economic, and cultural underpinnings of each of the

32 Hornberger Nelly, Bilingual Education and Language Maintenance: A Southern Peruvian Quechua Case, (Berlin: Mouton, 2019), 77. 


\section{Arabiyât Jurnal Pendidikan Bahasa Arab dan Kebahasaaraban, 8 (1), 2021}

international language teaching model as well as its institutional framework. ${ }^{33}$ The relevance of the analytic philosophy lies in the critical analysis of the various features of the institutional and operational frameworks of the models. This inquiry tool, it should be noted, takes a step beyond the participant-observer methodologies of ethnography. 34

Curriculum criticism is employed to examine the curricular and pedagogical implications of the models. It is also employed in picking holes in and exposing the strengths of each of the models. The relevance of this method to this research lies in the fact that it provides a more comprehensive view of curricular and educational needs, "Curriculum criticism is premised on an analogy between the curriculum (as a set of materials offering experience to its recipients) and the work of art in any medium. The curriculum critic attempts to portray the experience offered by the work and especially the experiences offered to students. The critic serves as a bridge between a curriculum and school officials who must make a decision about it. As regards creative synthesis, its relevance to this study stems from its nature as a tool for "combining of separate elements to form a coherent whole". 35 Creative synthesis, infact, is where lies the original contribution of the study as it seeks to systematically translate into a logically and sequentially interlinked whole fragments of best practices from the various models evaluated. Specific details of each of the five combined methods shall be provided in the full research plan.

For effective management and monitoring, the project is divided into five stages namely pre-field paper work, field survey, post-field synthesis, and finalization of report for submission. During the pre-field stage, the researcher intends to work closely with development experts in order to fine-tune the documentation in consonance with the priorities of the development sector. The preliminary documentation is expected to receive critical comments and contribution with potential to make the research and supporting instruments, better and of merit. The researcher shall rely on the guidance of development experts in selecting a representative sample of four countries to visit for the purpose of evaluating the institutional nature and operations of some of the dominant language teaching models and specifically for the purpose of data collection and administration.

This stage shall also witness the formulation of a detailed research plan and validation of instruments meant for use in the field, in keeping with principles of development focused research. The second stage is field research which comprises an active engagement with the institutional and operational frameworks of the models in selected countries. The researcher shall visit the selected countries, probably with one development expert, for the purpose of data collection and situational analysis. The third stage is post-field and covers the analysis of data from both the literature and the

33 Hornberger Nelly, Bilingual Education and Language Maintenance: A Southern Peruvian Quechua Case, 321.

34 Briggs Bogdan, Qualitative research for education: an introduction to theory and methods, (Boston: Allyn and Bacon, 1998), 221.

${ }^{35}$ Briggs Bogdan, Qualitative research for education: an introduction to theory and methods, 225. 


\section{Arabiyât Jurnal Pendidikan Bahasa Arab dan Kebahasaaraban, 8 (1), 2021}

field trip as well as a synthesis of best practices, where required. The fourth stage covers finalization of the research for knowledge sharing. The fifth stage is the experimental stage which requires extensive preparation for the composition of a team of Arabic curricularists, pedagogues, and teachers, with specific academic backgrounds, as participants for the use of the synthetic or newly designed framework which inevitably comprises new instructional materials. It is noteworthy that the present paper covers only stage 1 and some aspects of stage 2, while the stages not covered therein are subject of another article.

\section{Result and Discussion}

It is evident from the literature that there are various typologies of language education Mocinic identifies three forms namely Mainstream/Submersion Education, Mainstreaming With Pull-out Classes, and Segregationist Education. ${ }^{36}$ The first is described as "the assimilation of minority language pupils within the major schools, who are taught throughout the curriculum in the language of the majority, without paying attention to their mother tongue" 37 while the second involved "withdrawing minority language children from mainstream classes for compensatory lessons in the majority language", ${ }^{38}$ The third variant of bilingual education "occurs where minority language speakers and majority language speakers are completely divided: to minority children the access to majority schools is denied, they attend different schools where the program is taught in their own language". ${ }^{39}$ These three are characterized in literature as monolingual forms of education for bilinguals. It should be noted, however, that this study is not oblivious of the fact that the proposed language learning model, The Arabic World, is not exclusively school-based and that the frequent use of such terms as school, children, teachers, classes are by no means, restrictive.

However, another set of three is characterized as weak forms of language education. These are Transitional Bilingual Education, Mainstream Education with Foreign Language Teaching, and Separatist Education. The first teaches "minority children in their language until they are thought to be proficient enough in the majority language to cope with it in mainstream education" while the second situates "foreign language as one of the world mainstream languages e.g. Arabic, English, French, German, in view of its importance to the country or region. The third form which is called Separatist Education occurs where "a minority language tends to detach itself from the majority language which is why it is also called secessionist education. ${ }^{40}$

While the above three are tagged weak, a set of four different forms of language education have been described as strong. These are Dual Language Education, Heritage Language Education, Immersion Education, and Education in Majority Languages. The

\footnotetext{
${ }^{36}$ Baker Mocinic, "Bilingual Education", 177.

37 Baker Mocinic, "Bilingual Education", 178.

38 Baker Mocinic, "Bilingual Education", 179.

${ }^{39}$ Baker Mocinic, "Bilingual Education”, 180.

${ }^{40}$ Baker Mocinic, "Bilingual Education”, 179.
} 


\section{Arabiyât Jurnal Pendidikan Bahasa Arab dan Kebahasaaraban, 8 (1), 2021}

first form occurs when an "approximately equal number of minority and majority language students are in the same classroom and both languages are used during the lessons", the second occurs "when minority children are taught in their native or heritage language and the objective is achieving complete bilingualism". The third is targeted at teaching the curriculum in a second language, with the aim of producing efficient bilinguals while the fourth is where the majority would be for world spread languages like English, Arabic, French, German and others. What is specifically involved here is the use of two majority languages in a school. According to Mocinic, schools in this category are in society where the majority of the population is already bilingual or multilingual as is the case in Singapore and Luxembourg "where there is a significant number of people of different nationalities who want to become bilingual (e.g. English or Americans living in Japan)". ${ }^{41}$

It is noteworthy that it is premature to determine a model for this research in view of the fact that such an undertaking can only be contingent upon a critical evaluation of dominant international language pedagogical practices. Yet it is not premature to state that although somewhat indebted to the transitional model of bilingual education which aims to shift students away from the use of their L1 as quickly as possible towards the greater use of a foreign (L2) language, to enable them cope academically in mainstream education, the proposed project is unarguably faithful to the maintenance model which aims to "maintain the minority language of the student, strengthen his sense of cultural and linguistic identity and affirm their individual and collective ethnolinguistic rights", as well as to the enrichment model which "aims toward, not only maintenance, but development and extension of minority languages, cultural pluralism, and an integrated national society based on autonomy of cultural groups". ${ }^{2}$

The specific directions of the project may be viewed through the lenses of its objectives, research questions and hypotheses, as will be formulated in what follows. It should be noted that whatever seems confusing or inconsistent in the foregoing analysis will be thoroughly addressed in the extensive literature review for the study. Yet the salient underpinnings that connect the foregoing to the present study whose focus is dominant language pedagogical practices may be underscored in what follows, especially concerning the argument advanced earlier on language learning strategies.

One of the dominant models for evaluation in this research is that offered by the Goethe Institut whose primary concern is to promote the German language and culture through a multiplicity of windows. The Goethe Institut has been very consistent in its continued review and enrichment of its model through creative pedagogy and innovative instructional materials and practices. These include Double Club, The Smart Choice, The Language Magician, and German with Karla and Kai. The uniqueness of this model lies in its effective use of the entertainment strategies such as football and other sporting activities as vehicles in the pursuit of language teaching.

\footnotetext{
${ }^{41}$ Baker Mocinic, "Bilingual Education", 178.

42 Sawyer May, "Bilingual Education: What the Research Tells Us", 126.
} 


\section{Arabiyât Jurnal Pendidikan Bahasa Arab dan Kebahasaaraban, 8 (1), 2021}

However, it is paradoxical that fixed-effects regressions which showed a strong association between immigration and language learning in the European Union, by extension, showed that immigration by non-European Union citizens is strongly correlated with language learning in Germany. ${ }^{43}$ Consequently, commercial activities and other economic considerations are strongly associated with German language learning at the level of the Goethe Institut. ${ }^{44}$ This study shall engage critically with this and other themes and revelations emerging from the available body of scholarship on German language as promoted by the Goethe Institut. Such an enterprise shall be targeted at exposing the strengths and deficiencies of the model involved.

Cervantes Institute (Instituto Cervantes) is to the Spanish language, what the British Council is to the English Language and the Goethe Institute, to the German language. It was founded by the Parliament of Spain in 1991 to promote the Spanish language and culture throughout the world. The Cervantes Institute operates through two departments namely the Academic Department which takes charge of all activities concerning the teaching of Spanish as a second and foreign language, and the Cultural Department which is responsible for cultural and scientific matters. What distinguishes the Insitute from others is its attention to training and retraining of teachers for the Spanish language as well as the multiple nature of its cultural programmes. For instance, the Institute currently has 18,000 language courses and over 9, 000 cultural activities, for specific purposes ${ }^{45}$ Fernerdez has provided useful information concerning the strength of the Cervantes Institute: ${ }^{46}$

...the libraries of the Institute are connected as a network and they have more than 1,1 million of volumes. In 1997 the Centro Virtual Cervantes website was created, accessible on the Internet (http://cvc.cervantes.es) and... it is the most visited website in Spanish for language learning and cultural purposes. Among its contents are teaching materials, discussion forums, cultural reports, proceedings, and links to academic projects (Archivo Gramatical de la Lengua Española, Catálogo de voces hispánicas, ....). Furthermore, by the beginning of the twenty-first Century, the Cervantes created the AVE (Aula Virtual de Español), a digital platform whose main goal is to offer Spanish online courses via the Internet. The AVE Spanish course includes all levels of language learning according to the Common European Framework and it consists of modules and units. The material includes a statement of learning objectives for each section, text and audio samples, and some interactive activities (p. 17).

Specific details of some of the pitfalls associated with this model of language learning are provided in the extensive literature review.

As regards the promotion of the French language and culture, the Alliance Francaise (French Alliance) had been established since 1884 and had recorded

43 Ken Menken, English Language Learners Left Behind: Standardised Testing as Language Policy (Clevedon: Multilingual Matters, 2008), 131.

${ }^{44}$ Ken Menken, English Language Learners Left Behind: Standardised Testing as Language Policy, 131.

${ }^{45}$ Ken Menken, English Language Learners Left Behind: Standardised Testing as Language Policy 133.

${ }^{46}$ David Fernerdez, Bilingual Education, (Clevedon: Multilingual Matters, 2017), 101. 


\section{Arabiyât Jurnal Pendidikan Bahasa Arab dan Kebahasaaraban, 8 (1), 2021}

significant achievements. ${ }^{47}$ Yet, the long decades of success did not prevent some critical attitudes towards the prospects of French culture which, according to Anaytite (2015), 'have become especially widespread due to a scandal caused by Donald Morrison's article, 'In Search of a Lost Time'. ${ }^{48}$ Morrison had distinguished a major problem that sometimes puts to question the credibility and perceived success of French cultural diplomacy. That was characterized among others as lack of openness to foreign cultural elements which stems from the notorious tendency of the elite 'to keep out foreign entertainment products while subsidizing their own' ${ }^{49}$

In response to this criticism and in a bid to improve the quality of the output of French cultural diplomacy, the French political elite decided to create a more effective and functional institution with potential to accommodate prospective partners for the purpose of national and international cooperation. Consequently, the French cultural association known as Cultures France was transformed into Institute Francais in $2010 .^{50}$ The emergence of Institute Francais as a single system of French cultural associations invariably strengthened the performance of other cultural institutions under the leadership of the main suppoters of the Francophonie such as the French Alliance. ${ }^{51}$ There is no gainsaying that, as noted earlier, the French Alliance has made significant and almost unprecedented achievement in the area of language teaching and culture promotion. In curriculum, pedagogy, structure, evaluation and accreditation, the French model offered through this medium seems impressive even though there are few pitfalls that will be exposed by this study during its evaluation of the model.

This study shall also concerned about a relatively inclusive model funded by the European Union under the title Pan-European Task Activities in Language Learning (PETALL) project. ${ }^{52}$ Although this project is primarily concerned about the use of Information Communication Technology resources in language leaning, its predominance, as well as general acceptance and recognition among European language scholars, researchers and administrators as well as political goodwill and huge financial support it enjoys in official quarters at the level of the European Commission, makes it deserving of consideration in an evaluative study of this nature. Another strength of the PETALL project lies in its focus on language teachers and teacher trainees as well as researchers interested in exploring the interface between task-based language teaching (TBLT) and ICT in the light of the principle of Common European Framework of Reference, ${ }^{53}$

47 Don Madrid \& Saylor Julius, Quality Factors in Bilingual Education at University Level, (Porta Linguarum, June, 2017), 19.

${ }^{48}$ Donald Morrisson, "In Search of Lost Time”, Time Magazine, April 2, 2010.

${ }^{49}$ Donald Morrisson, "In Search of Lost Time".

${ }^{50}$ David Fernerdez, Bilingual Education, 103.

${ }^{51}$ David Fernerdez, Bilingual Education, 104.

52 PETTAL, "Pan-European Activities in Language Learning", Final Report, 2016, Public Part.

53 PETTAL, "Pan-European Activities in Language Learning", 2. 


\section{Arabiyât Jurnal Pendidikan Bahasa Arab dan Kebahasaaraban, 8 (1), 2021}

The specific pedagogical foci of the PETALL project are three namely the dynamics of collaborative work between language teachers in task and management, the centrality of evaluation tools to the quality of teacher education in technologymediated TBLT and the effectiveness of task-based language learning, as well as the best means to design and evaluate tasks and considerations with potential to ensure that the tasks proposed by the project travel well. In view of the above enumerated and other features of the PETALL project, especially in view of its relationship with every other dominant Western-oriented language teaching model, the present study deems it appropriate to subject it to a critical evaluation.

Like the dominant Western models of language teaching, some of the dominant Arabic models offered through the Teaching Arabic as a Foreign Language programmes in various parts of the Arab world, are also identified for evaluation. These include the Saudi Arabian model as offered by the Al-Imam Muhammad Ibn Saud Islamic University, Riyadh, the Qatari model, as offered by Qatar University, Doha, the Syrian model as offered by the University of Damascus, Damascus, the Sudanese model as offered by the International African University, Khartoum, the Egyptian model as offered by the International Language Institute, Cairo ${ }^{54}$. Two of top five Western models of teaching Arabic have also been selected for evaluation. These are the Oxford model which has been repeatedly ranked first among the leading universities for the teaching of languages, and the Harvard model which is ranked third in the world and first among American universities, in the area of language teaching. ${ }^{55}$ The evaluation of these seven Arabic teaching models shall be guided by the five curriculum evaluation questions generally known to the field of curriculum and pedagogy, ${ }^{56}$ especially in evaluating the existing Arabic language teaching models. The five curriculums evaluation questions are as follows:

1. The Question of Intrinsic Value which is interested in the degree of appropriateness of the existing Arabic education programme in a particular country;

2. The Question of Instrumental $V$ alue which is concerned with what is the existing Arabic teaching programme good for;

3. The Question of Comparative Value which seeks to determine whether a new Arabic teaching programme will be better or make a significant difference;

4. The Question of Idealization Value which is aimed at eliciting data that can provide some guidance concerning how to make an Arabic teaching programme the best possible; and

${ }^{54}$ Maha Al-Hendawi, "Teaching Arabic Language for Arabs: Challenges, Tensions, and the WayForward”, Designing and Effective Training Program, (Doha: Qatar University), 11.

55 Times Higher Education, THE Ranking, 2020.

${ }^{56}$ Allan Ornstein and Francis Hunkins, Crurriculum: Foundations, Principles and Issues, (New York: Reason Education, 2017), 371. 


\section{Arabiyât Jurnal Pendidikan Bahasa Arab dan Kebahasaaraban, 8 (1), 2021}

5. The Question of Decision Value which is interested in the documentation of evidence in such a manner that can facilitate decision on whether to retain, modify or discard a particular Arabic teaching programme.

Specific details of the implications of all these for the proposed project cannot be accommodated in this paper owing to space constraint.

\section{Conclusion}

This paper has attempted to examine the achievements of language pedagogical models to expose some of their strengths and deficiencies. In specific terms, the paper examined four dominant language pedagogical models namely the Alliance Francaise Model (for French), the Goethe Institut Model (for German), Instituto Cervantes Model (for Spanish), as well as the model offered by the European-funded Pan-European Task-based Activities in Language Learning (PETALL) project. The paper, in order to achieve an appreciable level of manageability, was focused on curriculum content and structure, pedagogical design and practices, evaluation and certification methods, as well as management and operations especially with regard to cultural, political and diplomatic considerations, to attempt a replication of the success story of some of the dominant, outcome-based language pedagogical practices in the context of Modern Standard Arabic.]

\section{REFERENCES}

Agnieszka, Stepkowska. "Language experience of immigrant women in bilingual couples with Poles”, International Journal of Bilingualism, July 2020.

Allan, Peter. Designing a School Curriculum. Boston: Allyn and Bacon, 1998.

Amanti, Catherine. "The (invinsible) work of dual language bilingual education teachers", Bilingual Research Journal, 2019.

Asiwaju, Akin. "Border Populations as a Neglected Dimension of the Study of Boundary Problems in Africa: The Case of the Nigeria-Benin Boundary", Paper presented at the request of the Nigerian Institute of International Affairs for its National Seminar on Nigeria's International Boundaries, April 7-8, 1982.

Asiwaju, Akin. Artificial Boundaries. University of Lagos Inaugural Lecture Series, Lagos: University Press, 1984.

Baker, Collins. Foundation of bilingual Education and Bilingualism. Clevedon: Multilingual Matters, 2007.

Baker, Collins., and Ann de Kanter. Effectiveness of Bilingual Education: A Review of the Literature. Washington, DC: US Department of Education, 1981.

Baker, Collins., and Prys Jones. Encyclopedia of Bilingualism and Bilingual Education. Cleverdon: Multilingual Matters, 1998. 


\section{Arabiyât Jurnal Pendidikan Bahasa Arab dan Kebahasaaraban, 8 (1), 2021}

Baker, Kliepart., and Ann de Kanter. Bilingual Education. A Reappraisal of Federal Policy. Lexington: Lexington Books, 1983.

Bialystok, Earnest. "Bilingualism in Development: Language", Literacy and Cognition, Cambridge: University Press, 2006.

Bogdan, Baker. Qualitative research for education: an introduction to theory and methods Boston: Allyn and Bacon, 1998.

Boggs, Wainne. International Boundaries: A Study of Boundary Function and Problems. Columbia: University Press, 1940.

Brochin, Car. "Queering bilingual teaching in elementary schools and in bilingual teacher education". Theory into Practice 2019: 80-88.

Conant, John. The education of American teachers. New York: McGraw-Hill, 1963.

Fishman, John. Bilingual Education: An International Sociological Perspective. Rowley: Newbury House, 1976.

Freeman, Roy. Bilingual Education and Social Change. Clevedon: Multilingual Matters, 1998.

Garcia, Oary. Bilingual Education in the $21^{\text {st }}$ Century: A Global Perspective. Malden: WileyBlackwell.

Garcia, Oary., and Cane Sylvan. "Pedagogies and Practices in Multilingual Classrooms. Singularities in Pluralities", Modern Language Journal, Vol. 95, No. 3, 2011.

Georgios., and Charalambos Themistocleaous. "Vowel learning in diglossic settings: Evidence from Arabic-Greek learners", International Journal of Bilingualism, July 2020 .

Guzman, Gloria., and Cham Johannessen. eds. "Bilingual Education: Politics, Policies and Practices in a Globalized Society", Springer, 2019.

Hakuta, Ken., and Elway Garcia. "Bilingualism and Education”, American Psychologist, Vol. 64, No. 2, 1989.

Hornberger, Nelly. Bilingual Education and Language Maintenance: A Southern Peruvian Quechua Case. Berlin: Mouton, 2019.

Hornberger, Noam. "Extending Enrichment Bilingual Education: Revisiting Typologies and Redirecting Policy", in Bilingual Education: Ornn Garcia, ed. Festschrift in honour of Joshua Fishman, Amsterdam: John Benjamins.

James, Cummins. "Linguistic Interdependence and the Educational Development of Bilingual Children”, Review of Educational Research, Vol. 49, No. 2, 1979.

James, Cummins. Negotiating Identities: Education for Empowerment in a Diverse Society. Toronto: California Association of Bilingual Education, 1996.

James, Cummins. Language, Power and Pedagogy: Bilingual Children in Crossfire. Clevedon: Multilingual Matters, 2000. 


\section{Arabiyât Jurnal Pendidikan Bahasa Arab dan Kebahasaaraban, 8 (1), 2021}

James, Cummins. "Bilingual and Immersion Programs", in The Handbook of Language and Teaching, eds. Long Martin and Cowan. (Malden: Wiley Blackwell), 161-181.

al-Janaideh, Redab., Kathleen Hipfner, Boucher, Patricia Cleave, Xi Chen. "Contributions of code-based and oral language skills to Arabic and English reading comprehension in Arabic-English bilinguals in the elementary school years", International Journal of Bilingual Education and Bilingualism, Vol. 5, No. 4, 2021.

Madrid, David., and San Julius. Quality Factors in Bilingual Education at University Level. Porta Linguarum, June, 2017.

Martell, Melissa Navarro. "Ciencias bilingues: how dual language teachers cultivate equity in dual language classrooms", International Journal of Bilingual Education and Bilingualism, Vol. 5, No. 4, 2021.

May, Saylor. "Curriculum and the Education of Cultural and Linguistic Minorities", in McGraw E. Baker,and Peter Peterson eds.), International Encyclopedia of Education, Oxford: Elsevier, Vol. 1, 2018.

May, Saylor. "Bilingual Education: What the Research Tells Us", in Garcia et al (eds.), Bilingual and Multilingual Education. Switzerland: Springer International Publishing, 2017.

Menken, Kliepard. English Language Learners Left Behind: Standardised Testing as Language Policy. Clevedon: Multilingual Matters, 2007.

Mocinic, Baker. "Bilingual Education”, Professional Articles, Vol. 13, No. 3, 2011.

Monnier, Catherine., Julie Booiche, Pauline Armandon, Sophie Baodoin, and Stephanie Bellocchi. "Is bilingualism associated with better working memory capacity: A meta analysis", International Journal of Bilingual Education and Bilingualism, Vol. 5, No. 4, 2021.

Nina, Dobrushina., and Olga Kultepina. "The rise of lingua franca,: The case of Russian in Dagestan”, International Journal of Bilingualism, October, 2020.

Ornstein, Allan., and Francis Hunkins. Crurriculum: Foundations, Principles and Issues. New York: Reason Education, 2017.

Taba, Hilda. Curriculum development: theory and practice. New York: Harcourt, Brace and World Inc, 1962.

Tyler, Ralph. Basic principles of curriculum and instruction. Chicago \& London: The University of Chicago Press, 1949.

Wilson, Sonia. "To mix or not to mix: Parental attitudes towards translanguaging and language management choices", International Journal of Bilingualism, March 4, 2020. 